Book review: CEE Feminisms

The Politics of Gender Culture under State Socialism: An Expropriated Voice. Edited by Hana Havelkova' and Libora Oates-Indruchova'. London: Rout- ledge, 2014.

Queer Visibility in Post-socialist Cultures. Edited by Narcisz Fejes and Andrea P. Balogh. Bristol: Intellect, 2013.

The Traffic in Women's Work: East European Migration and the Making of Europe. By Anca Parvulescu. Chicago: University of Chicago Press, 2014.

\title{
C. Laura Lovin
}

The volumes discussed in this review take up several inquiries into gen- der and sexuality coming from Central and Eastern Europe, a region whose production of feminist scholarship is usually deemed marginal when situated against the background of the production and circulation of transnational feminism. Against recurring refutations of CEE's status as a distinct region, particularly after the marketization of its economies after the fall of the statecommunist regimes in 1989 , these three new publications assert the value of the regional angle by creating an analytical arc that connects investigations of state-communist gender policies, discursive practices, and lived experiences to explorations of the change in visibility regimes around nonnormative sexualities that occurred after the fall of the Iron Curtain. The volumes also present critiques of the neoliberal moment through a theoretical engagement with newly articulated gen- der and sexuality regimes, an engagement that maps the exploitation of women's work and the distribution of women's precarity and vulnerability onto the former boundaries that separate the old Europeans from newer ones. Moreover, each volume challenges a view that presents the scholar- ship coming from the region as 
predominantly practice-oriented and abstracted from current feminist conceptual debates. In doing so, the authors trace multiple lines of connection and continuity between their interdisciplinary inquiries and the larger conceptual, topical, and empirical orientations of the field of women's and gender studies.

Originating from a three-year research endeavor, Hana Havelkova' and Libora OatesIndruchova's edited collection, The Politics of Gender Culture under State Socialism: An Expropriated Voice, brings together theoretically and methodologically diverse projects that look at CEE gender and sexuality cultures and share an overarching commitment to foregrounding the state-socialist period analytically. The volume is organized in two parts, with the first addressing gender as a social category while the second turns to symbolic representations of gender. Each individual chapter makes a compelling argument for disrupting representational regimes that render the cultural and sociopolitical realities of state socialism in monolithic terms and via binary notions of power and agency. The conceptual frameworks and the compelling corpus of sources assembled in the first part of the volume testify to the critical value of historical particularity and the finely tuned differentiation among subjects, practices, knowledges, temporalities, and locations.

While the socialist gender emancipation agenda is customarily remembered as a project managed by the state, the book cogently challenges the reductive notions behind the topdown women's emancipation paradigm by turning to textual and empirical evidence pertaining to gender-relevant social research, policy, jurisprudence, and organizational archives. For in- stance, Vera Sokolova' shows that the heteronormative agenda of Czechoslovakia was by and large articulated by sex experts, while Barbara Havelkova' emphasizes the historical reconfigurations of legal notions of gender 
equality by ideologically heterogeneous legal communities. In the context of women's organizations, Denisa Necasova' challenges the narrative that portrays these groups as "automatic and obedient executors" $73 \mathrm{P}$ of the ideological directions dictated by the Central Committee of the Communist Party (CCP). Whereas there's no doubt that the gender agenda shifted under the control of the party after 1948, Nec`asova's detailed documentation of the discontentment between the CCP and four women's organizations, whose "restructuring, demise or renewal" she traces across four de- cades, is in fact indicative of their open ideological conflict ð57p. Through archival work, Necasova' unearths ideological clashes between the two par- ties as well as the tactics and strategies put forth by women's organizations in order to alter the CCP's vision of women's roles and gender equality, thus making a timely and valuable contribution to the theorization of women's political agency under state socialism.

Approaching gender as a symbolic category allows Havelkova and Oates- Indruchova to mobilize sets of practices that disprove the conception that contemporary CEE feminisms and gender studies are "imported from the West" ð11P. By looking at films (Petra Hanakova, Katerina Kolarova', Oates-Indruchova), fiction (Jan Motonoha), sport events (Petr Roubal), and newspapers (Oates-Indruchova), the authors in the second part of the volume refocus this conversation by placing the formation of feminist and gender-sensitive thought against the knowledge production contexts that stretch across the nineteenth century, the first half of the twentieth century, and throughout the state-socialist period. Like the contributors to the first part, the authors assembled in the second part of the volume fore- ground the political moments that shaped local history e.g., the formation of the First Czechoslovak Republic, the end of the Second World War, perestroika and argue for a mode of analysis that is sensitive to continuities and discontinuities in the patriarchal discourse, as well as to the moments and 
contexts of pluralization of gender and sexuality discourses that take into account such categories as knowledge production communities, time, and location. For instance, in "The Beauty and the Loser: Cultural Representations of Gender in Late State-Socialism," OatesIndruchova juxtaposes a critical reading of two party newspapers with that of two novels that enjoyed mainstream circulation during the perestroika period. Together they account for moments of "discursive repositionings" of state- socialist notions of femininity and masculinity (189). Comparative historical analysis allows Oates-Indruchova' to conclude that the radical gender- emancipatory potential of the official rhetoric from the early years of state socialism was replaced, during the perestroika years, by traditional images of women as "helpmates" and by a "rhetoric of supermotherhood" (193).

While the content of the party newspapers falls squarely within the limits of what OatesIndruchova terms "authoritative ideological discourses," the two novels could potentially point to “emergent and alternative dis- courses” ð196P. Indeed, Oates-Indruchova shows that the female protagonist of For Reasons Unknown manifests her agency in relation to "the authoritative ideological discourse ... and the normative pressures of the regime" (204) by turning to individualism as well as to scripts of traditional pre-state-socialist femininity.1 Oates-Indruchova's comparative methodology genre and historical underscores the value of finely tuned contextualizations for theoretical models that account for discursive heterogeneity and that allow for the coevality of seemingly incongruous notions of gender.

The editors' careful attention to historical detail informs the theoretical framing of the volume, which is stated in its subtitle: An Expropriated Voice. For Havelkova and OatesIndruchova, the concept of expropriation de- scribes the relation between the feminist and gender-emancipatory agendas of pre-state-socialist and state-socialist times respectively. 
They argue that by expropriating the agenda of the pre-1945 women's movement, the Communist Party severed and rendered invisible complex genealogies of gender equality and emancipation, and most important, it subdued the transformative energy of state-socialist feminist voices. Unfortunately, the regional scope of the volume is much narrower than its title suggests, as its chapters ultimately comprise only a detailed and multifaceted examination of the Czechoslovak gender and sexuality regimes.

By turning to several CEE national contexts, such as Croatia and the post-Yugoslav region, the Czech Republic, Slovakia, Romania, Bulgaria, Russia, and the post-Soviet space, the editors of Queer Visibility in Post-socialist Cultures restore the national diversity of state socialism. Narcisz Fejes and Andrea P. Balogh propose "visibility" (3) as a conceptual framework for the volume's inquiries into the transformations undergone by LGBTQ lives and identities 1: “Queer Negotiations of Post-socialist Identities”, mobilizations and politics 2: “Queer Politics and Activism”, and representations 3: "Configurations of Queer in Postsocialist Film and Media." The erasure of geographical differences within the space of CEE, particularly in the Western commentary on CEE lesbian and gay rights movements, is rigorously problematized for its reinscription of hierarchical geopolitical divisions as well as homogenizing and exclusionary mappings of the European continent. The term “postsocialism" further articulates the volume's conceptual framework by positioning the current forms of lesbian, gay, and queer visibility in relation to the legacy of authoritarian control over the public sphere under state socialism. Through accounts that are sensitive to the temporality and geopolitical situatedness of LGBTQ visibility, Fejes and Balogh put forth a collection of articles that are invaluable to contemporary intersectional analysis of LGBTQ subjectivity formation and sexuality politics, particularly through their insights into coconstitutive mechanisms that link nonnormative gender and sexualities with ethnic and 
national identity formations within spaces of articulation that combine several scales, namely, those of the region, the nation, Europe, and the globe.

In "Now You See It: Gay In/Visibility and the Performance of Post- Soviet Identity," Brian James Baer explores the conceptual and affective realignments that followed the shift from the almost complete invisibility of homosexuality in popular culture and academic discourse during the Soviet period to a considerably increased post-Soviet visibility. Baer astutely points out that the intersection of geopolitical remappings of Europe, the marketization of post-Soviet economies, and the abandonment of Soviet censorship made for a politics of visibility that is far more complicated than would appear to be entailed by a mere transition from homosexual invisibility to homosexual visibility. The cone of visibility cast around lesbian and gay subjects thus functions within a patriarchal heteronormative order. On one side, linked to the post-Soviet "crisis of masculinity" (40), the visibility of homosexuality is feared for its power to seduce vulnerable young boys into life choices that result in moral destitution. But, the invisibility of homosexuality is no longer equated with its ontological absence as was the case during Soviet times but with the peril of gay men's passing as straight and their taking control of key sectors of Russia's economy and politics. At the same time, the post-Soviet politics of homosexual visibility is intertwined with the representational politics of national identity and continues to be shaped by meanings that render the lesbian and gay cultures of the gulag through the classed tropes of defiant and promiscuous sexuality. The meaning of nonheteronormative sexual excess is further mutated when placed in the context of the assertive politics of sexual identity, which at this point functions as a metonym for the United States or the West. Nicole Butterfield discusses various local articulations of these dynamics in "Sexual Rights as a Tool for Mapping Europe: Discourse of Human Rights and European Identity in Activists Struggles in Croatia." Ultimately, these chains of 
signification link the minority rights politics of Western democracies with notions of materialism and ex-acerbated individualism and end up rendering the political activism of gay and lesbian citizens incompatible with the universalism, spirituality, and in- tellectualism of Russian cultural citizenship.

The volume's explorations of such conundrums benefit scholars and activists by advancing significant analytical innovations and political implications. In "The Politics of Coming Out and Hungarian Nationalism," Eszter Timar stages a genealogical dialogue between the arguments pro- posed almost two centuries ago by two advocates of homosexual rights Karoly Kertbeny and Karl Heirich Ulrichs, the contemporary rationales of Hungarian nationalism, and the tenets of US multiculturalism in order to explain the discursive grounds of recent tensions between the LGBT politics articulated around coming out strategies and Hungarian assimilationist nationalism, which is rooted in a history of the exclusion of nonHungarian ethnicities from the national body politic. Timar argues that in the Hungarian context, the political visibility of difference, which is a significant dimension of the global LGBT movement, is translated by the radical Right into a notion of "foreignness" and thus ends up constructing homosexuality as an internal threat to national integrity.

The volume concludes with inquiries into the social change potential of LGBTQ cinematic representations. The Romanian blockbuster Legaturi Bolnavicioase (Love sick); directed by Tudor Ghiorghiu in 2006 is central to Zita Farkas and Aniko' Imre's chapters and their critiques of the lesbian visibility engendered by the film. In spite of the fact that the film tells the love story between two young women, Farkas demonstrates that Legaturi Bolnavicioase does not challenge the heteronormativity of Romania's main- stream media cultures. She attributes its popularity to its play on homo- phobic feelings and titillating images of 
commodified lesbianism. By com- paring the representational politics of the film to the visibility politics of the yearly gay pride parades in Bucharest, Farkas's critique calls for more politicized representational interventions, which challenge the containment and control that governs the parades or the spirit of "tolerance in the name of Love" (193) put forth by Legaturi Bolnavicioase.

In "Global Popular Media and the Local Limits of Queering," Imre looks at an impressively diverse corpus of films produced in the region over the course of the two decades that followed the dismantling of state- socialist regimes. Imre concurs with Farkas's conclusion with regard to Legaturi Bolnavicioase, and, furthermore, she is able to qualify the political potential of the various films sampled in her chapter by accounting for their contexts of production, their genre conventions, their distribution networks, and their spaces of reception. Some of these films successfully introduce nonnormative sexual subjects into mainstream media while also safely situating them outside the national space even as they address heterosexual audiences. The narrative arcs of self-representational documentaries bridge the "native/national" and "foreign/global" divides, and they succeed not only in bringing "lesbianism into representation" (238) but also in normalizing lesbians as integral and permanent members of national societies. Imre argues that factors such as the uneven distribution of media and artistic resources across rural/urban lines, regional divides, and hierarchized systems of national values limit the capacity of such public articulations to create political collectivities. Ultimately, a strikingly similar phenomenon is detectable across the ten essays included in Queer Visibility in Post-socialist Cultures, namely, the construction of LGBTQ people as a latent threat to the integrity of the nation. 
While the first two volumes assemble a complex picture of CEE gender and sexuality cultures, politics, and activism, Anca Parvulescu's The Traffic in Women's Work: East European Migration and the Making of Europe offers a compelling argument for a new Europe, whose formation rests on the extraction of Eastern European women's gendered and racialized la- bor. In an interdisciplinary endeavor whose explorations cross disciplinary boundaries, Parvulescu's analysis sets in dialogue recent European films and social theories of human mobility, gendered labor, and racialization in order to unearth the meanings and the vocabularies; the subjects and the agencies; the needs, desires, and relationships; as well as the policies and politics that enabled the formations of post-state-socialist circuits of traffic in East European women's work. The Traffic in Women's Work launches an ambitious theoretical endeavor in taking up pressing questions about the emotional, social, economic, and administrative dimensions of intra- European relations in the context of their emergence, implications, and possible modes of redress. By situating Gayle Rubin's discussion of gender in the transnational context of the "European family" (2), Parvulescu theorizes the cinematic instances of exchange in Eastern European women by and among men across the continent and posits that in light of contemporary phenomena of "transnational migration and reproductive technologies" (29), Judith Butler's disavowal of the explanatory power of structuralist frameworks of kinship was stated too soon.

Parvulescu begins by tracing the networks of exchange that undergird the traffic in women and the European marriage market through a reading of Cristian Mungiu's 2002 film Occident. Luce Irigaray's search for the symbolic and sexual conditions that enable practices of exchange that bypass the traffic in women inspires the volume's explorations of alternative practices of sociality, work, mobility, and politics. Its first chapter looks at the journeys of two young Romanian women, Sorina and Mihaela, both of whom marry abroad. Whereas 
Sorina decides to marry abroad in order to leave the economic precarity of her life as a kindergarten teacher, Mihaela's trajectory complicates binary notions of agency, selfdetermination, and subjectivity. By abiding by her parents' plans for her to marry an Italian man, Mihaela could be viewed as a "mere object of traffic in the global European moment" (46), and yet, as Parvulescu points out, Mihaela is a subject whose future is open. Parvulescu concludes her reading of Occident by imagining for Mihaela an Iragarayan trajectory: once in Italy, Mihaela works hard to fulfil her passion for writing, eventually becoming one of the female voices whose new language denotes the symbolic and material conditions of women's exchange in contemporary Europe.

What makes Parvulescu's work ground-breaking is the explanatory power that she invests the notion of the "traffic in women." She re-creates it as an analytical term that is sensitive to the rhetorical, political, and economic rearrangements required by the eastward enlargement of the European Union i.e., the European Union's figuration through tropes of kinship or family, and the emergence of institutional practices that continue to dis- tribute opportunity, precarity, and vulnerability unevenly. For Parvulescu, the concept of "traffic in women" problematizes the systems of exchange that emerge at the intersection of post-Fordism, Western feminism, globalization, and austerity policies and the outsourcing of reproductive work previously performed by Western European women to non-European and Eastern European women, who "create life and community, in precarious labor situations with no labor rights, no protection, and no guarantee for remuneration" (30). Ulrich Seidl's 2007 film Import/Export constitutes the cinematic entry point into the second chapter of the book-a persuasive critique of the transnational commodification of the Eastern European women's care, domestic, and affective work. The trajectory of Seidl's protagonist, Olga, demonstrates the interplay between kinship, mobility, and the markets for reproductive work: in Ukraine, 
Olga provides unpaid care for her family and works in nursing as well as in the cybersex industry. Work emigration brings her into the space of middle-class Austrian households, as a “stateless foreigner" and "second-class citizen” $\Varangle 58 \mathrm{P}$ who cleans and takes care of the elderly. The concept of "traffic in women" further allows Parvulescu to situate the work opportunities open to Eastern Europeans on a continuum shaped by the hierarchies of EU citizenship as well as the gender, racial, and sexual dimensions of the new European division of labor. Parvulescu next tackles the traffic in Eastern European women's biological reproductive capacities, through a reading of Giuseppe Tornatore's 2006 film The Unknown Woman. Her theoretical engagement with Giorgio Agamben's concept of the homo sacer leads to a conceptual framing of the conditions that allow for the traffic in Eastern European women's work through the notion of the camp: "the sex trafficking camp, which distributes reproduction" (72). Irene, Tornatore's protagonist, illustrates the transmutations in subjectivity undergone by the camp subject. Whereas Irene is captured into the circuits of sex trafficking, the conventions of the thriller genre disable her subjectivity as a victim. The combined analytic of Rubin and Agamben allows Parvulescu to argue that, first of all, it is Irene's killing of another human being that prevents the audience from identifying with her as a victim. However, the development of her character provides another critical point: as a subject of the camp, Irene can only regain her agentive subjectivity and re-enter law as a criminal. The displacement of the victim figure from the center of the sex-trafficking discourse is valuable to Parvulescu for its capacity to refocus viewers' attention on the symbolic and material contexts that produce narratives of victimization. The spatiality of the traffic in women's work remains central to her examination of instances of filtered mobility and stratified precarity, brought about by the hierarchization of European passports. In her reading of Lukas Moodysson's 2000 film Lilja 4-Ever and Jean-Pierre and Luc Dardenne’s 2008 Lorna's Silence, Parvulescu deemphasizes the analytics of the border and argues that 
the differentiation between "strong" and "weak" passports determines the parameters of contemporary mobility. The shift to a spatiality marked by lines of division that follow variations in economic status rather than political attachments coalesce traffickers' ability to exploit the differential effectiveness of European passports in the formation of mobility effects, which, as in the case of Moodysson's character Olga, "trouble the legal assumption that the perfect victims of sex trafficking are distinguishable from economic migrants" (107). Even when the transnational patriarchal family shifts to "looser, half-formed relationships, neither biologically reproductive nor necessarily heterosexual" (116) manifestations of kinship, Eastern European women's work continues to be arrested by neocolonial circuits of exchange. Parvulescu concludes with a search for instances of sociability, work, and intimacy that resist exploitation. I hope that scholars and students of women's and gender studies, European studies, and migration studies will be inspired to continue the explorations she so compellingly began with this volume. 